\title{
CHARACTERISTICS OF THE SEASONAL SEA ICE OF EAST ANTARCTICA AND COMPARISONS WITH SATELLITE OBSERVATIONS
}

\author{
by \\ T.H. Jacka, I. Allison, R. Thwaites \\ (Antarctic Division, Department of Science, Kingston, 7150 Australia) \\ and \\ J.C. Wilson
}

(Bureau of Meteorology, Department of Science, Melbourne, 3000 Australia)

\begin{abstract}
A cruise to Antarctic waters from late October to mid December 1985 provided the opportunity to study characteristics of the seasonal sea ice from a time close to that of maximum extent through early spring decay. The area covered by the observations extends from the northern ice limit to the Antarctic coast between long. $50^{\circ} \mathrm{E}$ and $80^{\circ} \mathrm{E}$. Shipboard observations included ice extent, type and thickness, and snow depth. Ice cores were drilled at several sites, providing data on salinity and structure.

The observations verify the highly dynamic and divergent nature of the Antarctic seasonal sea-ice zone. Floe size and thickness varied greatly at all locations, although generally increasing from north to south. A high percentage of the total ice mass exhibited a frazil crystal structure, indicative of the existence of open water in the vicinity.

The ground based observations are compared with observations from satellite sensors. The remote sensing data include the visual channel imagery from NOAA 6 , NOAA 9, and Meteor 11. Comparisons are made with the operational ice charts produced (mainly from satellite data) by the Joint Ice Center, and with the analyses available by facsimile from Molodezhnaya.
\end{abstract}

\section{INTRODUCTION}

Because Antarctica has no permanent population and is distant from international travel routes and areas of major strategic importance, there are few observations of sea-ice characteristics from within the seasonal sea-ice zone. Our knowledge of winter ice conditions comes almost solely from relatively coarse resolution passive microwave and infrared satellite imagery.

Most sea ice in the Antarctic is believed to be of one type (first-year ice) and hence it has been assumed that the ice concentration can be obtained from passive microwave data, analysed using simple algorithms based on the difference between the microwave emissivity (at $19 \mathrm{GHz}$ ) of water and a unique value for ice (e.g. Comiso and Zwally 1982; Zwally and others 1983). There are, however, few ground-based data to verify these algorithms. Comiso (1983) suggested that using multi-spectral cluster analysis techniques, the satellite data themselves can be used to identify the microwave characteristics of different ice types (including new ice), but there still remains a need for in-situ validations.

Ackley and others (1980) made observations of ice characteristics in the Weddell Sea from USCGC Polar Sea in February/March 1980. Comprehensive observations in the same area were made in late spring (October/November, 1981) from NES Mikhail Somov during the Weddell Polynya Experiment. The latter study produced detailed data on sea-ice conditions (Ackley and Smith 1983) and on the physical, chemical and biological properties of sampled ice floes (Ackley and others, 1983). Comiso and others (1984) compare the in-situ data from Mikhail Somov with Nimbus-7 SMMR data and conclude that the $18 \mathrm{GHz}$ channel gives good discrimination of the ice edge but that in late spring and summer, surface wetness leads to differences identifiable by multi-spectral cluster analysis, particularly in the $37 \mathrm{GHz}$ emissivity. These differences would cause errors in the ice concentrations if a unique ice emissivity was assumed. Comiso and others (1984) stress the importance of surface observations to aid interpretation of satellite data but, while there is an ongoing winter sea-ice program in the Weddell Sea, no previous winter data have been reported from other areas of Antarctica.

The data presented in this paper were collected on board MV Nella Dan between early October and mid December 1985, in the Indian Ocean sector of the seasonal sea-ice zone. Climatic ice data (e.g. Zwally and others 1983; Jacka 1983) show that the maximum extent of the ice in this sector occurs in October. In contrast, the maximum extent in the Weddell sector occurs from mid September to mid October and the data reported to date from the Weddell Sea have been from the period of decay of the annual ice cover.

The cruise of Nella Dan was primarily for biological studies (Antarctic Division Biomass Experiment III; ADBEX III) but included a sea-ice subprogram. Observations of sea-ice conditions were made about every $5 \mathrm{~km}$. A number of vertical photography runs over the pack ice were made from a helicopter, and cores were collected for study of the physical and structural properties of the ice. Automatic Picture Transmission (APT) data were received on board from NOAA 6, NOAA 9 and Meteor 11 satellites.

The cruise track of Nella Dan is shown in Fig.1. The ship entered the pack at long. $60^{\circ} \mathrm{E}$ on 8 October and worked southwards until 17 October but was unable to penetrate beyond about $64^{\circ} \mathrm{S}$. A region of lower concentration ice to the north of the Enderby Land peninsula was exploited to then work south towards the coast. Nella Dan's track south was approximately along $55^{\circ} \mathrm{E}$ until poor weather, strong winds and south-west running leads eventually led to the ship approaching the Antarctic coast near $50^{\circ} \mathrm{E}$. In this area, Nella Dan became beset and remained so, in a large consolidated floe, drifting slowly west for 7 weeks. MV Icebird was unable to approach closer than $18 \mathrm{~km}$ to Nella Dan in early December because of severe ice conditions in a shear zone. Nella Dan was eventually freed on 15 December by the Japanese ice breaker Shirase.

\section{ICE CONDITIONS IN THE MARGINAL ICE ZONE}

The marginal ice zone (MIZ) is the outer region of a sea-ice field, where oceanic and atmospheric interactions with pack ice are at their most dynamic. In the area close 


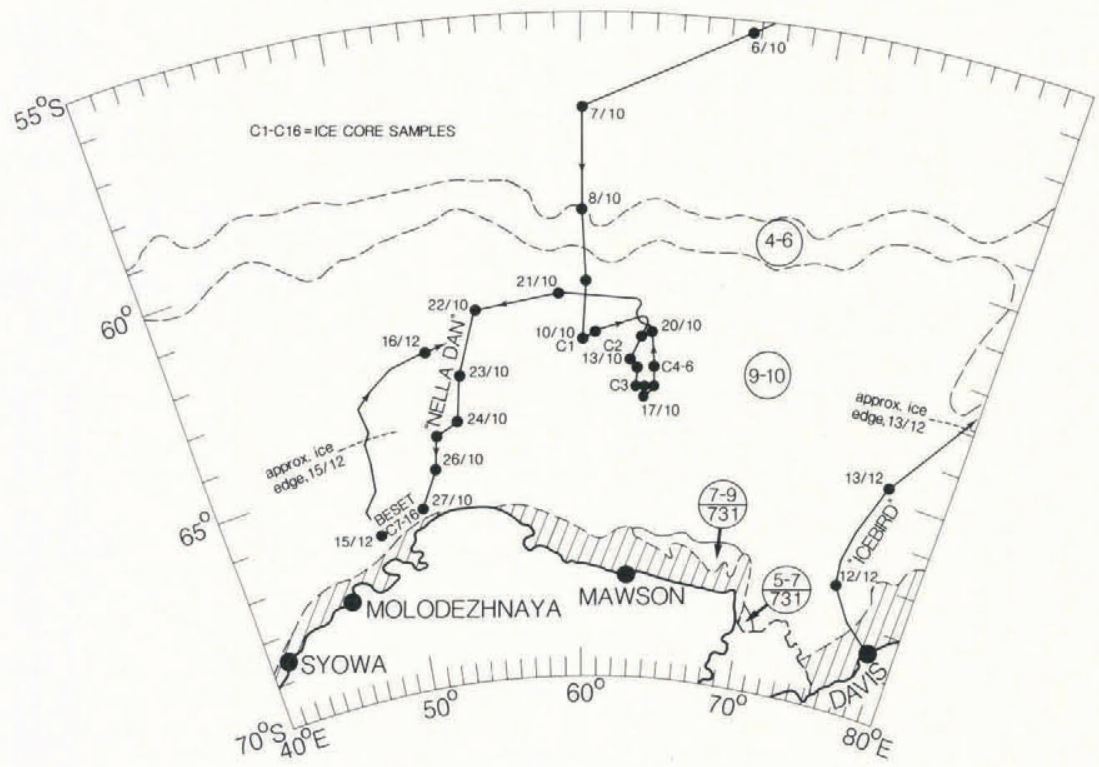

Fig.1. Cruise track of MV Nella Dan during ADBEX-III, 1985. Ice boundaries and concentrations (shown in the standard "egg" code) are from the US Navy-NOAA Joint Ice Center ice chart for 10 October 1985

to the open ocean the ice has properties quite different from those of ice in the interior pack (typically more than $150 \mathrm{~km}$ from the ice edge) and special techniques may be required to obtain estimates of ice characteristics from remote-sensing data (NASA 1984).

The change in ice conditions across the late winter Antarctic MIZ along $60^{\circ} \mathrm{E}$ longitude is summarized in Fig.2 from observations made from Nella Dan. In the first 100 to $150 \mathrm{~km}$ from the ice edge (at $59^{\circ} 32$ 'S), the floe size and ice thickness generally increase and the ice type becomes increasingly more mature. The floe size affects such largescale properties as the mechanical strength of the ice as a continuum and summer melt from the sides of the floes. Rothrock and Thorndike (1984) discuss the detailed measurements required to determine the floe size distribution. The data of Fig.2 give the typical range of floe sizes as estimated from the ship. Similarly, the ice thicknesses given are estimates only and, where the pack consists of a mixture of new and more mature ice forms, the range of thicknesses given is typical of that of the older floes. These shipboard observations were made by three observers. To ensure consistency of their estimates of thickness, floe size and concentration, the initial observations during the cruise were made simultaneously but independently by all observers and single observer estimates were used only after the observers had achieved a consistent standard. Throughout the MIZ, newly formed ice (nilas, pancakes, young ice, etc.) constitutes a significant percentage of the total ice cover. The structure of the pack ice in the late winter MIZ contrasts with that seen during the summer. Figs 3 and 4 show north-south transects from the interior ice near the coast to the ice edge, observed from MV Icebird and MV

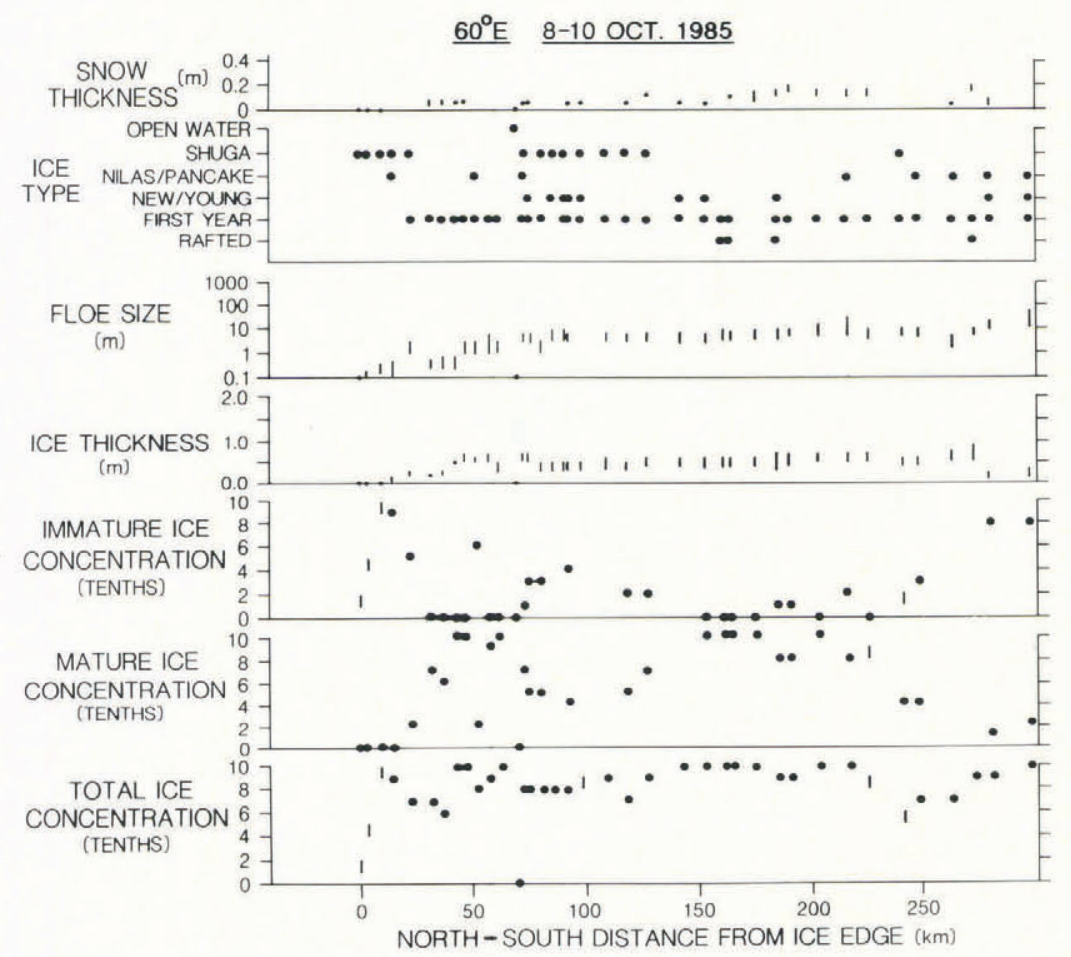

Fig.2. Sea-ice conditions observed on board Nella Dan along a north-south transect through the MIZ at $60^{\circ} \mathrm{E}$, October 1985. Ice concentration is shown for mature and immature ice forms as well as a total. Immature ice includes nilas, pancakes and new ice and is typically less than $0.4 \mathrm{~m}$ thick. 


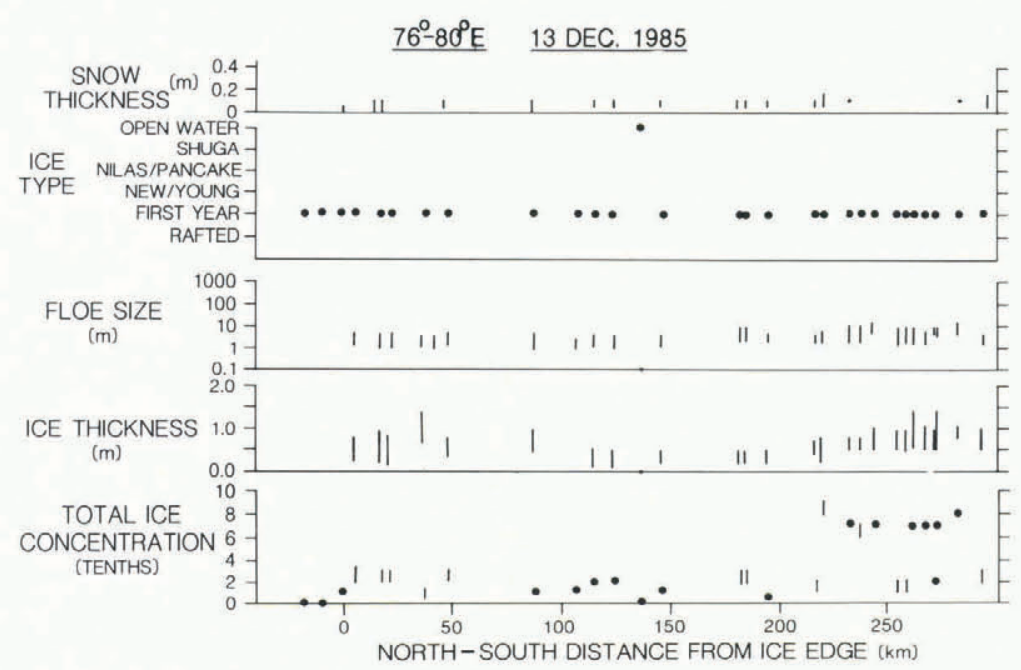

Fig.3. Sea-ice conditions observed on board Icebird along a north-south transect through the MIZ at $76-80^{\circ} \mathrm{E}$, December 1985.

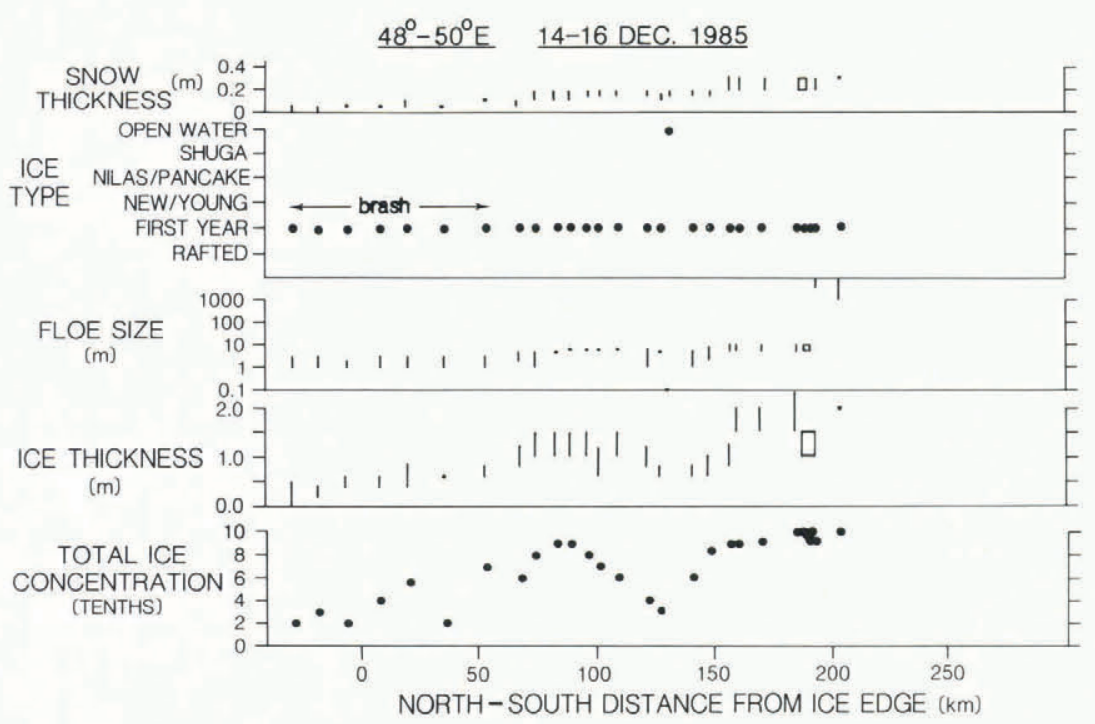

Fig.4. Sea-ice conditions observed on board Nella Dan along a north-south transect through the MIZ at $48-50^{\circ} \mathrm{E}$, December 1985.

Nella Dan respectively in December 1985. At this time the pack is much more uniform in ice type and floe size since all the thin ice forms have melted, and the low ice concentrations in the outer $200 \mathrm{~km}$ allow waves to break up the remaining first-year floes.

\section{ICE CONDITIONS IN THE INTERIOR ICE ZONE}

The ice conditions deeper within the seasonal ice zone are summarized in part of Fig.2 (beyond $150 \mathrm{~km}$ ) and in Fig.5, which shows a transect in mid October along approximately $55^{\circ} \mathrm{E}$. The floe sizes in this region are determined more by constructive processes (freezing together of smaller floes and brash ice) than by the destructive process of fracture. Nella Dan eventually became entrapped in a huge consolidated floe of approximately $20 \mathrm{~km}$ diameter. Even within the interior pack, $10-20 \%$ of the ice typically consisted of thin new ice types but this new ice was concentrated in wide leads, rather than being spread fairly uniformly as in the MIZ. Nella Dan was, however, following a route through systems of leads and polynyas. Extensive rafting of new and young ice up to $0.5 \mathrm{~m}$ thick occurs throughout the interior ice zone, and this contributes to the thickening of the ice cover. Only in the strong shear zones nearer to the Antarctic coast, do pressure ridges of up to $3 \mathrm{~m}$ in height develop due to rafting of thicker ice.

A $7 \mathrm{~km}$ wide band of landfast ice west of $51^{\circ} 50^{\prime} \mathrm{E}$ longitude was separated from the pack by shore polynyas several kilometres wide, and a large polynya of tens of kilometres diameter lay to the north of Enderby Land, around $65^{\circ} 40^{\prime} \mathrm{S}, 52^{\circ} 20^{\prime} \mathrm{E}$.

\section{COMPARISON WITH SATELLITE-DERIVED CONDITIONS}

ICE

The value of remote sensing, particularly with passive microwave and active Synthetic Aperture Radar systems, to the delineation of ice extent and to the study of sea-ice processes has been well demonstrated. However, most researchers investigating the climatic role of sea ice, or studying ice-weather relationships, rely not on raw data from these systems but on derived products (such as the ice charts produced by the U.S. Navy/NOAA Joint Ice Center), on time-averaged compilations of satellite passive microwave data (e.g. Zwally and others 1983) or on the more easily obtainable visible and infrared imagery from polar orbiting weather satellites. Ice conditions from these sources are compared with the surface observations from Nella Dan.

APT data (in low resolution format) from the AVHRR on NOAA 6 and NOAA 9 and from Meteor 11 were routinely received on board Nella Dan. These data were limited by cloud which obscured surface conditions and by the extremely oblique viewing angles of some images. For good orbit geometry and largely cloudless conditions, the 


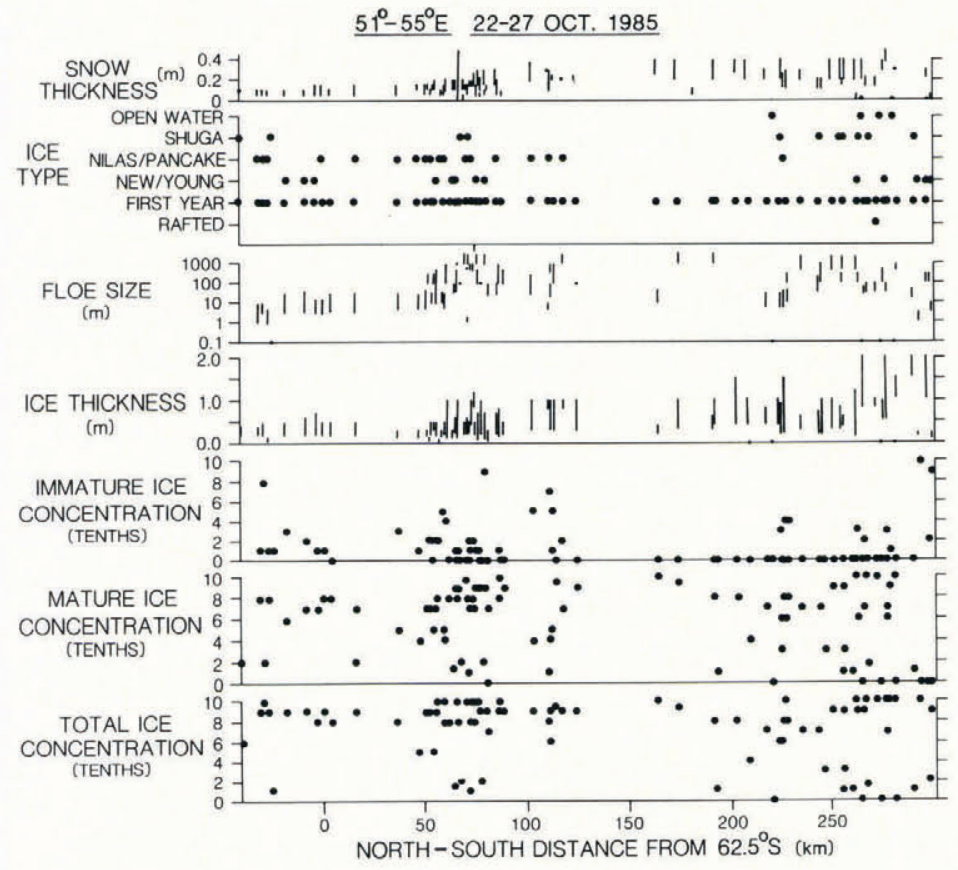

\section{FIGURE CAPTIONS}

Fig.5. Sea-ice conditions observed on board Nella Dan along a north-south transect through the interior pack at $51-55^{\circ} \mathrm{E}$, October 1985. Ice concentration is shown for mature and immature ice forms as well as a total.

Meteor pictures were superior for ice interpretation to those from NOAA. Fig.6 shows a Meteor 11 (visual band) picture for 10 October 1985 and an ice chart interpreted from this image. Also shown is a map drawn from the ice chart for the period 11-20 October 1985 which was transmitted by facsimile from the Soviet Antarctic Station, Molodezhnaya. These operational charts are prepared on the 1st, 11th, and 21 st of each month, and are largely based on APT data. The ice concentration contours from the JIC chart of 10 October 1985 are plotted on Fig.1 along with the track of Nella Dan.

Although Fig.6b and 6c show a very similar fast ice extent near the coast, the operational chart (Fig.6c) shows an average ice concentration in the interior pack higher than that in Fig.6b. Fig.6c represents the mean ice conditions for the ten-day period, and hence does not show fine detail, and some of the difference may be due to changing ice conditions during the analysis period (e.g. the ice concentration around $50^{\circ} \mathrm{E}$ increased considerably in the latter part of the period). The interpretation of ice concentration from the satellite imagery may, however, also differ between charts.

The system of leads and polynyas extending south towards the coast can be seen in the Meteor image. Strong west to south-west winds in the rear of a series of deep low pressure systems helped produce these open conditions. It would appear from satellite imagery and aerial observations over a number of years that this area of lower concentration is a semi-permanent feature (Knapp 1966).

Thorough analysis of the Meteor 11 picture can provide a detailed description of ice concentrations, and three categories are shown in Fig.6b. The general pattern of this detailed analysis agrees with the variable nature of the ice recorded on board Nella Dan. This detail is not displayed by either of the operational charts, but the more general concentration of $8-10 / 10$ throughout the interior ice zone is not incompatible with the ground-based observations. The sea-ice data derived from ESMR data for 1973-1976 (Zwally and others 1983) show typical October ice concentrations in this region of $8-9 / 10$. Both the Molodezhnaya and JIC charts show an outer ice band, of about $100 \mathrm{~km}$ width, of $4-6 / 10$ concentration. The actual concentration in this zone was greater than $7 / 10$, although much of this cover consisted of ice less than $5 \mathrm{~cm}$ thick, and thus was not detectable by the satellite sensors.

The winter ice charts are based exclusively on satellite data (IR and microwave) but unfortunately only an estimated ice edge is shown on the JIC chart for 10 October. The extent of fast ice from the analysis of the Meteor 11 picture, the Molodezhnaya chart and the JIC chart show good agreement. The northern ice limit interpreted from the Meteor 11 picture is further south than shown on both the operational charts, which, however, agree to better than the resolution of the microwave sensor $(\sim 30 \mathrm{~km})$ with the ship-based observations.

The Meteor 11 picture was scaled by using known latitudes and longitudes of identifiable locations on the picture. Small errors in scaling are possible due to the projection of the picture. In addition, the picture is an instantaneous record of sea-ice conditions while the operational charts are based on data collected over a period of about a week. These may account for the above discrepancy.

The ice concentrations observed in the marginal ice zone in December along $80^{\circ}$ and $50^{\circ} \mathrm{E}$ longitude (Figs 3 and 4) were, in both cases, lower than the 4-6/10 concentrations shown in the JIC chart for 12 December. Zwally and others (1983) also show monthly mean concentrations derived from the ESMR data that are somewhat higher at this time of year than reported here. It is difficult to resolve this apparent anomaly. Changes in the ice emissivity due to melt processes can result in errors in ice concentrations (Comiso and others 1984) of 3 to $4 \%$ at $19 \mathrm{GHz}$. Sea-ice concentrations derived from ESMR data, however, are only made to the nearest $10 \%$. In addition, no large-scale surface melt was observed, and thus it seems unlikely that melt processes could account for the total anomaly. Streten and Pike (1985) noted from shipboard observations in the same region and during the same season that satellite visual imagery frequently did not resolve low concentrations in the range $0-2 / 10$.

The ice edge shown on the JIC ice chart for 12 December is in general agreement with that observed from Nella Dan and from Icebird (Figs 3 and 4), although at this time of year direct comparisons should not be made. The JIC reports the mean ice conditions determined over a one 

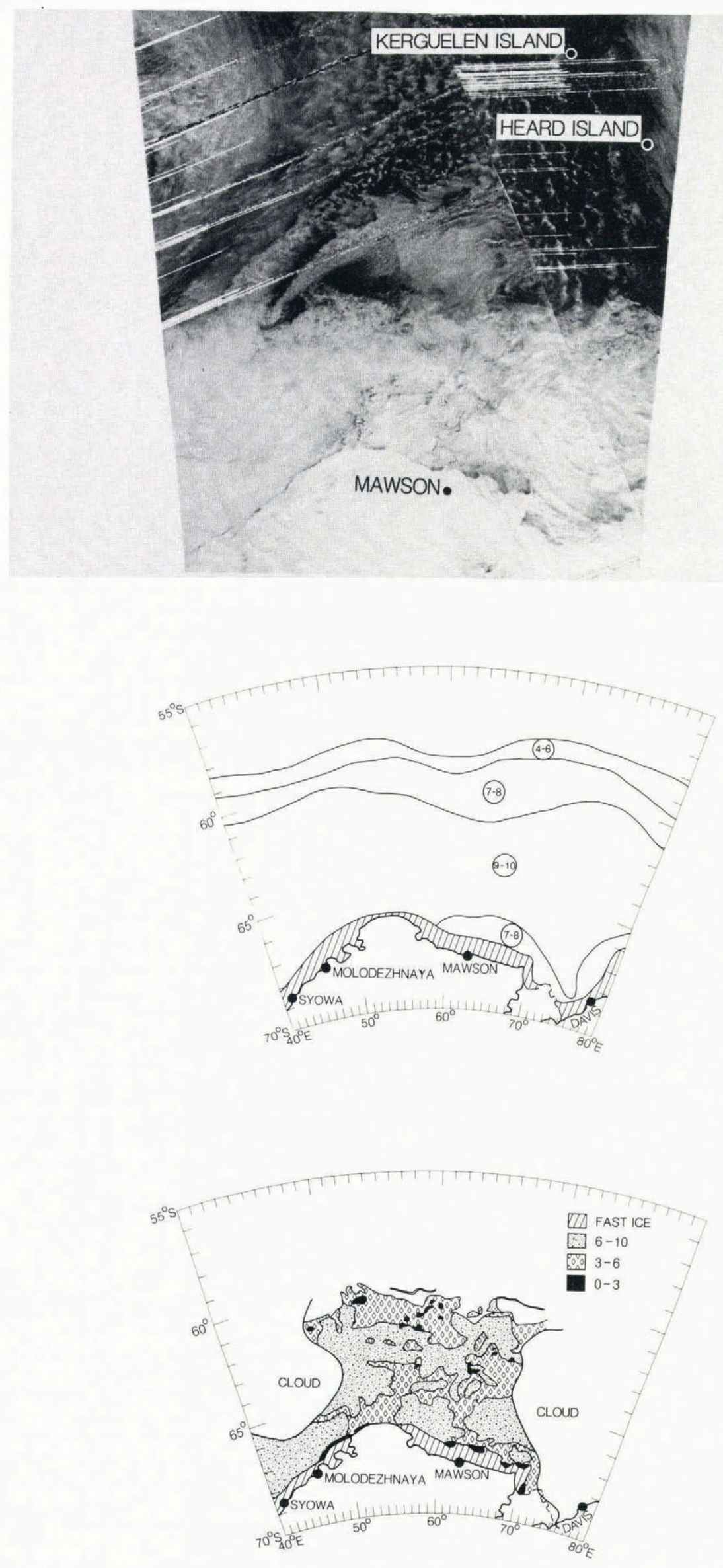

Fig.6. (a) Meteor 11 visual image of the observational area on 10 October 1985; (b) a detailed analysis of the image showing three levels of concentration; and (c) the analysis available by facsimile from Molodezhnaya for the period 11-20 October 1985 
week period, and in mid December the ice edge retreats at up to $200 \mathrm{~km}$ per week. Bands of small floes and brash ice, from 100 to $1000 \mathrm{~m}$ wide, were observed at distances up to $100 \mathrm{~km}$ north of the ice edge. Martin and others (1983) have studied the movement and decay of similar bands in the Bering Sea and consider them to play a major role in controlling the ice-edge position.

\section{PHYSICAL AND STRUCTURAL PROPERTIES OF THE PACK ICE}

Ice cores were taken from floes at sites shown in Fig.1, and these are described in Table I. The cores were examined structurally and sampled every $0.1 \mathrm{~m}$ for salinity measurements. Core samples were melted shortly after collection, and salinities were determined from measurements of the specific gravity at constant temperature. The resulting profiles are shown in Fig.7. Few of the cores exhibited the

TABLE I. AVERAGE COMPOSITION OF ICE CORES

Weighted average composition (\%)

\begin{tabular}{llccc}
\hline Core & Typical & Infiltration & Congelation & Frazil \\
number & depth $(\mathrm{m})$ & ice & ice & ice \\
\hline $1-6$ & $\sim 0.8$ & 7 & 37 & 56 \\
$7-16$ & $>2.5$ & 2 & 40 & 58 \\
\hline TOTAL & & 3 & 40 & 57 \\
\hline
\end{tabular}

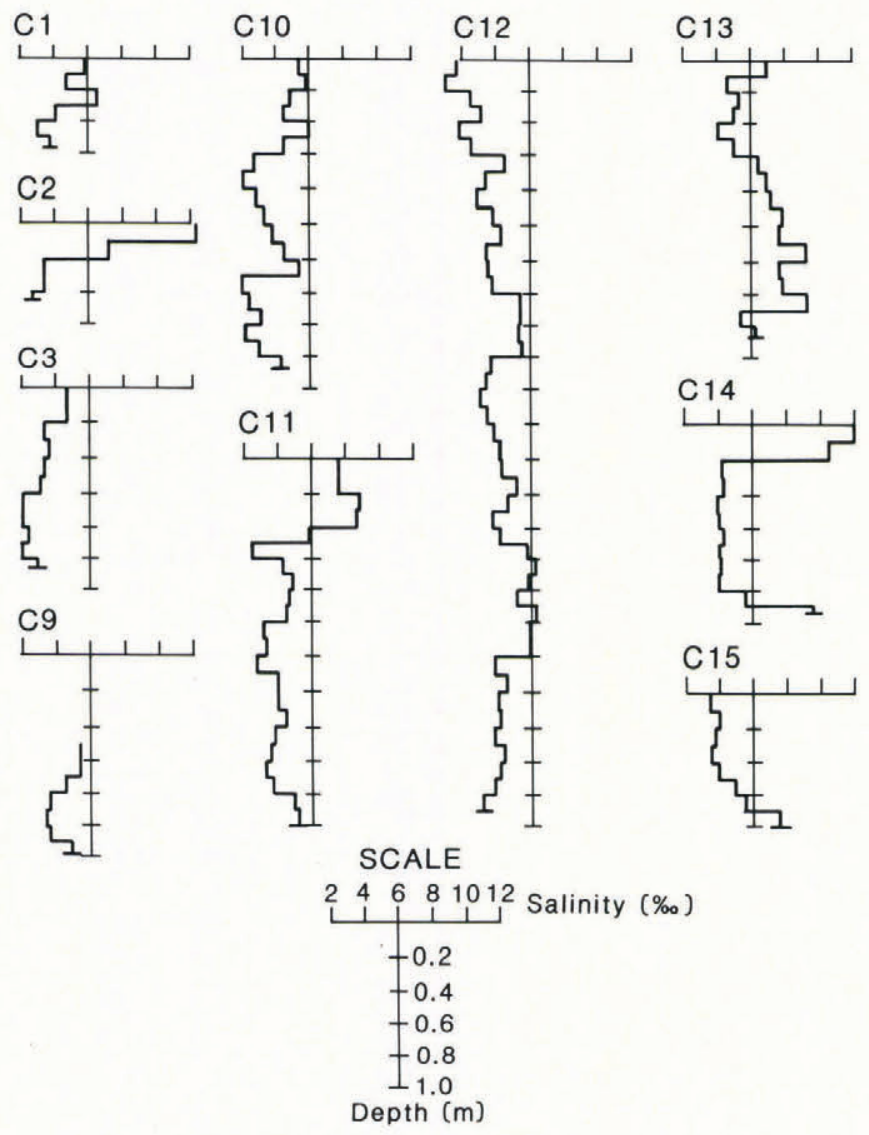

Fig.7. Salinity profiles from cores drilled at locations shown in Fig.1. characteristic C-shaped salinity profile typical of first-year fast ice, but cores 10 and 12 in particular show "stacked $\mathrm{C}^{\text {" }}$ profiles indicative of multiple rafting of floes, each typically $0.6-0.8 \mathrm{~m}$ thick.

The ice structure was determined from examination of thick longitudinal sections between crossed polarizing filters. Three major ice types were identified from the examination: ice with long columnar crystals originating from congelation growth; fine-grained frazil crystals; and infiltration ice formed from freezing of water-saturated snow. Almost all the examined cores show a very high fraction of frazil ice, which is similar to what was found in the Weddell Sea by Gow and others (1982), where many floes contained more than $50 \%$ frazil ice. They suggested that much of this frazil originates as a result of brine convection induced by rapid freezing of sea water in leads and polynyas, and that the widespread distribution of frazil in the Weddell Sea indicates the importance of ice deformation.

The area of ice sampled in cores 1 to 6 was quite different from that sampled in cores 7 to 16 . Cores 1 to 6 were obtained from young ice floes less than $1 \mathrm{~m}$ thick and within $300 \mathrm{~km}$ of the ice edge. Cores 7 to 16 were obtained when the ship was beset near the coast in ice more than $2 \mathrm{~m}$ thick. Notwithstanding these differences, the average fraction composition of the ice at both sites (Table I) was remarkably similar, with more than $50 \%$ of the total column being composed of frazil ice.

Studies of sea-ice structure at Casey in 1983 (Allison and Qian 1985) showed that frazil ice only contributed significantly to the total ice fraction when there was open water within $100 \mathrm{~m}$ or so of the fast ice. The large frazil fractions found in all cores hence suggest that divergen motion and lead formation is common in this region of the Antarctic seasonal sea-ice zone.

\section{SUMMARY AND CONCLUSION}

The observations from Nella Dan show that there is a wide mixture of ice type, age and thickness throughout the late winter Antarctic seasonal sea-ice zone in the region studied. The total ice concentrations are generally 9-10/10, but a high fraction of this ice cover is very young and of ten less than $10 \mathrm{~cm}$ thick. This has important implications for the energy exchange between the ocean and atmosphere. For example, in the central Arctic the total heat input to the atmosphere from regions of young ice may be equal to or greater than that from regions of open water or thick ice (Maykut 1978).

More than half the total ice column in the cores examined was composed of frazil ice, a similar fraction to that found in the Weddell Sea by Gow and others (1982). If frazil formation is widespread in the Antarctic seasonal sea-ice zone, there are important implications both for dynamic sea ice models and for the energy exchange. The dynamic models require a theoretical ice thickness distribution which presently does not allow for ice growth by frazil accretion. Similarly, the shift of frazil formed in leads and polynyas to other parts of the pack keeps the leads open as areas of very high ice formation rates and as areas of high heat loss. Current energy calculations do not take account of persistent leads.

Rafting of ice less than about $0.5 \mathrm{~cm}$ thick also contributes to the ice thickness development. Extensive rafting was observed in the interior ice zone. Large ridge building only occurred in a few areas near the coast.

The observed nature of the pack, and the ice core structure found, result from the relatively rapid and generally divergent motion of the Antarctic pack ice. This stresses the importance of ice dynamics as well as thermodynamics to large-scale sea-ice interaction in the Antarctic (Hibler and Ackley 1982).

The JIC and Molodezhnaya ice charts, derived from satellite imagery, give a reasonable representation of the Antarctic ice extent and broadscale concentration within the interior pack. In the marginal ice zone, however, thin new ice is not detected and the charts underestimate total ice concentration. Neither do they indicate the considerable percentage of young ice in the interior pack. These ice charts are widely used by many researchers as a primary sea-ice data source for ice and climate interaction studies. 
Because of the importance of thin ice to the surface energy balance, their use for this purpose should be treated with caution.

\section{REFERENCES}

Ackley S F, Smith S J 1983 Weddell Polynya Expedition. Sea ice observations. Reports of the U.S.-U.S.S.R. Weddell Polynya Expedition, October-November, 1981. Vol 5. Hanover, NH, US Army Cold Regions Research and Engineering Laboratory

Ackley S F, Gow A J, Buck K R, Golden K M 1980 Sea ice studies in the Weddell Sea aboard USCGC Polar Sea. Antarctic Journal of the United States 15(5): 84-86

Ackley S F, Clarke D B, Smith S J 1983 Weddell Polynya Expedition. Physical, chemical and biological properties of ice cores. Reports of the U.S.-U.S.S.R. Weddell Polynya Expedition, October-November, 1981. Vol 4. Hanover, $\mathrm{NH}$, US Army Cold Regions Research and Engineering Laboratory

Allison I, Qian Songlin 1985 Characteristics of sea ice in the Casey region. ANARE Research Notes 28: 47-56

Comiso J C 1983 Sea ice effective microwave emissivities from satellite passive microwave and infrared observations. Journal of Geophysical Research 88(C12): 7686-7704

Comiso J C, Zwally H J 1982 Antarctic sea ice concentrations inferred from Nimbus 5 ESMR and Landsat imagery. Journal of Geophysical Research 87(C8): 5836-5844

Comiso J C, Ackley S F, Gordon A L 1984 Antarctic sea ice microwave signatures and their correlation with in situ ice observations. Journal of Geophysical Research 89(C1): 662-672

Gow A J, Ackley S F, Weeks W F, Govoni J W 1982 Physical and structural characteristics of Antarctic sea ice. Annals of Glaciology 3: 113-117

Hibler W D III, Ackley S F 1982 On modelling the Weddell Sea pack ice. Annals of Glaciology 3: 125-130

Jacka T H 1983 A computer data base for Antarctic sea ice extent. ANARE Research Notes 13

Knapp W W 1966 Formation, persistence and disappearance of open water channels related to the meteorological conditions along the coast of the Antarctic continent. W.M.O. Technical Note 87: 89-104

Martin S, Kauffman P, Parkinson C 1983 The movement and decay of ice edge bands in the winter Bering Sea. Journal of Geophysical Research 88(C5): 2803-2812

Maykut G A 1978 Energy exchange over young sea ice in the central Arctic. Journal of Geophysical Research 83(C7): 3646-3658

NASA 1984 Passive microwave remote sensing for sea ice research. Report of NASA Science Working Group for the Special Sensor Microwave Imager $(S S M / I)$. Washington, DC, University of Washington. Applied Physics Laboratory

Rothrock D A, Thorndike A S 1984 Measuring the sea ice floe size distribution. Journal of Geophysical Research 89(C4): 6477-6486

Streten N A, Pike D J 1985 Sea ice observations during ADBEX, 1982. ANARE Research Notes 28

Wadhams P, Squire V A 1983 An ice-water vortex at the edge of the East Greenland Current. Journal of Geophysical Research 88(C5): 2770-2780

Zwally H J, Comiso J C, Parkinson C L, Campbell W J, Carsey F D, Gloersen P 1983 Antarctic sea ice, 1973-1976: satellite passive-microwave observations. Washington, DC, National Aeronautics and Space Administration (SP-459) 